\title{
Martineau, Cobbe, and Teleological Progressivism
}

\section{Introduction: Victorian Progressivism}

Variants of the view of history that I call progressivism were widely held in Victorian Britain. In this section I introduce this view, clarifying why progressivism often took teleological form; then I explain why I am focusing on the versions of teleological progressivism adopted by Harriet Martineau and Frances Power Cobbe, and why it is fruitful to consider these two women's views together. ${ }^{1}$

History arose as a discipline in the nineteenth century, and so did philosophy of history. There was deepening recognition that philosophy, thought, and ideas have a history, along with increased philosophical reflection on the nature of history, both as past events and as a branch of knowledge. Historicism was articulated, i.e., the thesis that everything in human life and thought has a history, and that no universals or absolutes stand outside the historical ebb and flow.

However, historicism had a problem. If everything is historical, then so is the knowledge that everything is historical. In that case, the knowledge that everything is historical is not trans-historically or absolutely true after all. Historicism threatened to undermine itself, a problem that motivated another position, progressivism. On this view, all of history is progressing towards the realization of a single goal, which gives us a yardstick by which to measure how advanced different times and places are. The historical story is one of advancement, not mere change. Progressivism gets around the historicist problem because on

\footnotetext{
${ }^{1}$ My thanks to the referees for their extremely helpful, careful, and constructive comments on earlier versions.
} 
this view it is progress, including intellectual progress, that explains our growing knowledge about the pervasiveness of history and shows that that knowledge is true.

Many Victorians subscribed to progressivism, both philosophically and sociopolitically. Legislation and agitation against slavery; expansions of the franchise; gains in women's rights; economic growth; industrialization, technological development, and scientific discoveries - all seemed to exemplify progress. Progress was central to many thendominant theories such as Spencer's evolutionism, Comtean positivism, and Hegelian idealism. Darwinism too was generally received as a progressivist theory. Higher Criticism the German-derived school of biblical and religious criticism that filtered out the historical truths in the Bible from the mythical and symbolic additions - also contributed to progress in its proponents' eyes. It marked a progressive extension of reason, free inquiry, and historical method into an area that had been off-limits. Its link with progressivism was cemented by the Westminster Review, which championed both Higher Criticism and theories of organic social evolution under the editorship of John Chapman and (anonymously) George Eliot in the early 1850s. Their 1852 "Prospectus" was an important statement of Victorian progressivism: The fundamental principle of the work [the Westminster Review] will be the recognition of the Law of Progress: ... attempts at reform ... should be directed and animated by an advancing ideal, [so] the Editors will maintain a steady comparison of the actual with the possible, as the most powerful stimulus to improvement. (Eliot, "Prospectus")

But progressivism contained a tension of its own. If a single goal drives the entire historical process, then that goal must in some way be present throughout the process. Otherwise, if the goal only came into being at some point in history, how could it possibly have guided the developments that occurred before it even existed? The goal of history must therefore be trans-historical; yet here progressivism was at risk of losing the key historicist 
insight that change is ubiquitous and affects everything. In response, the progressivist could say that although the goal exists from the very start of history, that goal at first exists only in nuce or potentially, subsequently becoming unfolded through the historical process. So the goal's level of reality and development, and the shape in which it manifests itself, change over time, even though its bare existence does not. On this compromise position, the goal is partly historical and partly trans-historical. This position is teleological progressivism: history has a telos, which is to realize, unfold, elaborate, and fulfil a potential, goal, or aim that has always existed from history's very beginning.

Martineau and Cobbe both developed original versions of teleological progressivism. Sadly, these have not been recognized as the contributions to nineteenth-century philosophical reflection on history that they were. Since Martineau and Cobbe were two of the best-known and most widely-read intellectual women in nineteenth-century Britain, it is important to correct their omission from the historical record and so more accurately map the full wealth of thought about historical progress in the period.

It is worth considering these two women together for several reasons. First, Cobbe formed her account of progress partly in critical reaction to Martineau's account. Martineau espoused progressivism in many places, but the most complex and philosophically elaborated was Eastern Life: Present and Past, from 1848. Cobbe read this work and reacted against it in her own writings on progress, which span the 1860s to 1870 s. Second, Cobbe's crucial disagreement with Martineau was about whether the goal of historical progression is religious or secular; Cobbe thought the former, Martineau the latter. Considering Cobbe and Martineau together brings this key point of dispute into focus. Third, despite their disagreement over religion, Cobbe's and Martineau's accounts of history share certain overarching structural features, which are illuminated when we consider the accounts together. Fourth, these structural similarities are connected with these women's broadly shared stances on 
Eurocentrism and colonialism, so that, again, considering Martineau and Cobbe together enables us to bring these complex issues into view.

Although Cobbe responded to Martineau's work, I doubt that all these structural similarities arise from direct influence of Martineau on Cobbe. More plausibly, they arise because both women were operating within the same overarching Victorian intellectual horizon and grappling with the same basic issues: how to understand historical progression; where that progression left religion; and how the progression related to European global dominance and Britain's imperial power.

One might infer from these two women's disagreement over religion that Cobbe is partisan whereas Martineau approaches religion, ideas, and their history with neutral, scholarly detachment. But that is not how their disagreement is best understood. To be sure Cobbe was a Christian, and she traces how other world-religions anticipate Christianity; whereas Martineau filters out core secular ideas within the sequence of world-religions up to and including Christianity. But Martineau had been very devout early in life. She only gradually abandoned Christianity, completing that abandonment through the experiences and thinking distilled in Eastern Life. Here she portrays religion as having always been secular at its core and being destined over history to realize this telos and transcend itself. Thus, as Martineau moved away from Christianity herself, she read the history of religion as making the same movement of self-overcoming. Let's turn now to the details of her account.

\section{Martineau on Progress}

Martineau was, in the words of a recent essay collection, a "nineteenth-century intellectual powerhouse" (Weiner and Sanders, Harriet Martineau). Raised in a progressive Unitarian milieu, she started off a firm Christian, publishing many essays on philosophical and religious 
topics over the 1820s. What shot her to fame was her Illustrations of Political Economy of 1832 - didactic tales illustrating principles like the law of supply and demand and the benefits of free trade. The Illustrations made Martineau a "literary lion", as she put it. Everyone courted her company, politicians sought her advice, and she was thrown into the centre of earlier nineteenth-century intellectual life. She toured the U.S., writing the 1838 methodological essay How to Observe Morals and Manners on the transatlantic crossing. Society in America, of 1839, diagnosed the fundamental contradiction between America's democratic principles and its practice of slavery. Martineau's many subsequent works include Eastern Life of 1848, our focus here; Letters on the Laws of Man's Nature and Development of 1851, an epistolary exchange with the 'phreno-mesmerist' George Atkinson and a bold declaration of naturalism, materialism, and atheism; her condensed translation of Comte's Course of Positive Philosophy from 1853; and her two-volume Autobiography, written in 1855 (though only published posthumously, in 1877). Across these works, and over the 1830s and 1840s, Martineau increasingly questioned her initial Christian faith, which she rejected by 1850 in favour of secularism, for reasons explored here.

Given the range of Martineau's work, scholars have variously categorized her as a journalist, author, intellectual, and sociologist (e.g., David, Intellectual Women; HoeckerDrysdale, Harriet Martineau). Yet Martineau was also, in part, a philosopher. ${ }^{2}$ Many of her works address philosophical matters - such as her Comte edition, early essays, and Eastern Life - while her more empirical works remain philosophically informed.

\footnotetext{
${ }^{2}$ See Meyers, "Martineau's Autobiography”. Pace Odile Boucher-Rivalain, who denies that Martineau ever identified as a philosopher ("Harriet Martineau”, 25), Martineau’s Autobiography abounds with references to her philosophy and self-descriptions as a philosopher (e.g., Autobiography, 1: 103-11, 158, 426).
} 
Progressivism was key to Martineau's philosophical position. For her, there was progress across history and modern European society stood at its summit so far. Martineau theorized the nature and criterion of progress philosophically, in fact providing several consecutive such theorizations. In How to Observe Morals and Manners, her criterion of social progress was how far a society embodies a sense of fraternity or solidarity. In Eastern Life, she took progress to obtain in the historical sequence of philosophical-religious Ideas. In the 1850 s she adopted a positivist conception of progress, subscribing to Comte's law that all societies develop through three stages: theological, where events are explained by divine legislation; metaphysical, with events explained by abstract causes, forces, and powers; and "positive", where events are explained scientifically and our knowledge of the laws regulating observed phenomena is organized into a system. The positivist conception of progress informed Martineau's Autobiography, in which, as she portrays things, she advanced from morbid, gloomy childhood religiosity, through adolescent metaphysical fogs, to the joyful and adult daylight of science, when she threw off religion's baleful influence. ${ }^{3}$ Within this personal progression Martineau identifies her experiences in Egypt and the Near East as the turning-point when she became convinced of the need to move beyond Christianity. These were the experiences that informed Eastern Life.

Martineau toured Egypt, Sinai, Palestine, and Syria from late 1846 to mid-1847. By then, such tours had become fashionable and several thousand Europeans had taken them. Florence Nightingale took one shortly after Martineau, and Cobbe followed suit, unaccompanied, in 1857-8. Several travellers published accounts of their journeys. Martineau's Eastern Life is one such, but it also contains “one of the most searching philosophical accounts of Egyptian travel in English" (Gange, Dialogues with the Dead, 109).

\footnotetext{
${ }^{3}$ On the autobiography's positivist structure, see Petersen, Autobiography, ch. 5.
} 
Martineau's travels, she says, transformed her perception of the "genealogy ... of the old faiths, - the Egyptian, the Hebrew, the Christian and the Mohammedan" (Martineau, Autobiography, 2: 279). Seeing the places, monuments, artefacts, and rituals linked to these faiths, in a geographical order that mirrored their chronological emergence, revealed to her the necessity of the "passage" and "progress" through these faiths (2: 280). It was a necessary course of progression which she had already mystically foreseen in 1845 :

I saw the march of the whole human race, past, present and to come, through existence, and their finding the Source of Life. Another time, I saw all the idolatries of the earth coming up to worship at the ascending series of Life-fountains, while I discovered these to be all connected, - each flowing down unseen to fill the next... ${ }^{4}$ Eastern Life implies that the next step in this ascending series is secularism. After some soulsearching, Martineau judged it safest not to state this openly in Eastern Life. But the book's "infidel tendency" did not escape her intended publisher, John Murray, who refused it on this account, or the many reviewers who found the book incendiary and objectionable. ${ }^{5}$

Yet Martineau's "necessary passage" is not an untroubled linear rise up the series of religions. She tells a more complicated historical story, which has two sides. Its first side is to the fore in Part I of Eastern Life, which is on ancient Egypt, occupying nearly half the book. Here Martineau argues that ancient Egypt's culture, religion, and philosophy lie at the origin of Western civilization. They are the source from which ancient Greece, Judaism, and Christianity arose, and the matrix of belief within which contemporary Christian Europe remains unknowingly located.

\footnotetext{
${ }^{4}$ Martineau, letter to Monckton Milnes, 22 Feb 1845, quoted in Roberts, Woman and the Hour, 149.

${ }^{5}$ See Gange, Dialogues with the Dead, 110; Roberts, Woman and the Hour, ch. 6.
} 
Egyptian "religious philosophy", for Martineau, has the following elements.

(1) Belief in a single God but under various attributes, powers, and manifestations that were elevated into deities in their own right. The "Egyptian priests upheld the doctrine of the unity of God ... The leading point of belief of the Egyptians ... was that there was One Supreme, - or, as they said, only one God" (Eastern Life, 100). We may wonder whether Martineau is projecting proto-Christian monotheism onto the ancient Egyptians, who prima facie were polytheists. The mid-fourteenth-century BC ruler Akhenaten introduced monotheism, but this was short-lived. That said, earlier on, the Egyptian pantheon did contain a chief deity - first Ra, later Amun or Amun-Ra. So if Martineau's claim about Egyptian monotheism simplifies things, it is not altogether baseless.

(2) Commitment to theocracy: a ruling caste of priests monopolized knowledge of the unity of God while fostering belief in polytheism, myth, ritual, and symbolism in the common people.

(3) Preoccupation with life and death, a consequence of Egypt's environment and the all-pervasive contrast between the abundant Nile (life) and arid desert (death). The constant awareness of potentially imminent death led to belief in "the Immortality of the Soul, and rewards and punishments in the afterlife" (85), and belief that all life and organized living bodies are sacred - hence the practice of mummification, including of sacred animals.

Egyptian religious philosophy, Martineau argues, shaped ancient Greek philosophy, Judaism, and Christianity. Greek civilization "unquestionably derived” from Egypt (91). Egyptian ideas especially influenced Greek philosophy, she explains: Thales studied in Egypt with the priests, as did other pre-Socratics including Pythagoras. His belief in immortal souls undergoing successive reincarnations was essentially Egyptian and influenced Plato, who spent time in Egypt too. Thus ancient Greece, the supposed foundation-stone of Western civilization, was at its core Egyptian. 
As for Judaism, Moses was an Egyptian, educated amongst its priestly caste, from whom he imbibed monotheism. His revolutionary move was to democratize monotheism and demote idol-worship and superstition in favour of adherence to a divinely legislated moral law. This idea of divine law, like that of one god, was Egyptian: "the great doctrine of a Divine Moral Government was the soul alike of the practical legislation of Moses and the speculative philosophy of Plato" (85).

Through these Greek and Judaic routes, and by direct influence, Egypt also lies at the origins of Christianity. In addition to the worshipping of one God, the mythology of Osiris prefigures and shapes that of Christ's death and resurrection; the creation story in Genesis derives from Egyptian creation myths; ideas of immortal souls and bodily resurrection come from Egypt and reappear, inter alia, in Paul's talk of the resurrection of our spiritual bodies. Overall, considering the Hebraic context in which Christianity arose: "It cannot be overlooked ... how large was the Egyptian element, in comparison with every other ... The Hebrew mind was fed by the Egyptian incessantly" (374).

In declaring that ancient Egypt is "the key" to Western civilization (374), Martineau subscribes to what Martin Bernal calls the "ancient model”, on which ancient Greek culture derived from Egyptian influence (Bernal, Black Athena). A key exponent of this model was Herodotus, to whom Martineau refers copiously, endorsing his view that Greece began as an Egyptian colony. Many Europeans accepted the ancient model right into the mid-nineteenth century, Bernal argues, but then the "Aryan" model supplanted it. On the Aryan model, Egypt's early influence notwithstanding, Greek culture essentially derived from later influences from incoming Indo-European - 'Aryan' - peoples. The Aryan model took hold, for Bernal, because on the ancient model Western civilization stems from Africa; but, according to the racial hierarchy that became entrenched over the nineteenth century, Africans 
are black and black people are uncivilized; so Africans cannot possibly have originated Western civilization.

Did Martineau see the Egyptians as black? Not unambiguously. She maintains that in their iconography the Egyptians depicted themselves in dark red, distinguished from Asiatics, Northerners (painted white) and Africans (painted black) (Eastern Life, 161). Martineau herself categorizes the Egyptians as 'Nubian' in ethnic terms, with "dark bronze" skin (86) i.e., half-way between African and Mediterranean. ${ }^{6}$ Still, it follows that for Martineau Western civilization did not originate with white Europeans, for whilst the Egyptians were not straightforwardly black, neither were they straightforwardly white.

Martineau chastises her European contemporaries for viewing Egyptian culture as primitive, deficient, and impoverished. She insists that all major faiths are noble and should be approached respectfully, sympathetically, and with an open mind. After all, Christianity's core ideas of monotheism and moral law stem from Egyptian religion: "historical and philosophical knowledge ... reveal the origin and sympathy and intermingling of the faiths of men, so that each may go some way in the interpretation of the rest" (356). Martineau effectively offers Christians a choice: condemn Egyptian religion as superstitious idolatry, but then Christianity stands condemned too; or concede their kinship, and that Egyptian religion is as noble as the Christianity that descends from it.

\footnotetext{
${ }^{6}$ Pace John Barrell, "Death on the Nile", who claims (1) that Martineau regarded the Nubians as black and (2) that she was consequently troubled about black people having originated Western culture. Even if (1) is true, which I doubt, (2) Martineau was happy to recognize black people as having culture-originating genius; she wrote a fictionalized biography of the Haitian revolutionary leader Toussaint L'Ouverture to bring “into full notice the intellectual and moral genius of as black a negro as was ever seen" (Autobiography 2: 160).
} 
So far, Martineau seems not to uphold progressivism but to assert the continuity between ancient and modern cultures and to question European Christianity's claim to be more advanced than other world religions. However, the progressivist side of her views emerges in Parts 2 to 4 of Eastern Life. In Part 2, on Judaism, she argues that despite Moses' attempt to democratize monotheism and establish a pure moral law, the Jews were too steeped in the pre-existing superstitious mind-set of popular Egyptian culture to take up his innovations. Hence Judaism fell back into ritual observances and practices, the letter not the spirit of the law. In addition, Moses' God became the tutelary deity of the Jews - another particular, not universal, deity. Moses had endeavoured to purify the noble kernel of Egyptian religion from the baser elements mixed with it: the combination of secretive priesthood with popular polytheism, idolatry, and rituals. Over time these base elements had brought Egyptian religion into decline as the people grew increasingly superstitious and the priests increasingly secretive. Relatively, then, Moses initiated a progressive advance. Yet his purified faith fell back into renewed forms of superstition, ritual, and particularity.

Tackling Christianity in Part 3, Martineau places Jesus in the context of a Judaic faith that had declined into superstition and was being challenged by sects like the Essenes, whose concern with the moral law Jesus pushed further. He sought to purify monotheism, eliminate superstitious rituals, simplify doctrine, and re-centre religious behaviour around universal moral principles. Against Pharisaic law-worship, he envisaged a spiritual kingdom that would render law redundant. Again, the purification effort failed. People began to "overlay the simple teachings of Jesus with mysteries and allegories and fables" (413). These were of Egyptian origin, for Egyptian culture remained the central cultural influence (373-4). Myths about Osiris (and his Greek analogue Pan) were superimposed onto Jesus, hence the growing preoccupation with Jesus' miraculous birth, death, and resurrection rather than his teachings and accomplishments in life. Jesus' attempted re-orientation towards moral conduct in life 
became overlaid with doctrines about the soul's fate in the afterlife. This was consolidated in the Alexandrian, Platonized form of Christianity that remodelled it around prior Egyptian beliefs.

Martineau's account of Christianity is both influenced by Higher Criticism and makes a key contribution to it. ${ }^{7}$ Martineau distinguishes the different voices in the Gospels and other New Testament books; she filters out the historical Jesus from the mythical elements subsequently imposed on him. She also gives this history/myth distinction her unique twist. The historical element was Jesus' attempt to purify monotheism and morality; the mythical element was the superimposition of Egyptian-derived myths, rituals, and symbols which dragged Christianity back down into superstition.

By now Martineau's positive evaluation of Egypt from Part 1 appears to have undergone a reversal. Egypt's influence on Christianity now looks overwhelmingly negative, with Egyptian culture blamed for dragging Christianity down into superstition, ritual, etc. "Till the religion taught by Jesus is purged of its Egyptian, Greek, Assyrian and Pharisaic accretions and adulterations ... its failure in regenerating the world will remain what it now is", Martineau says (430). She laments the "superstitions which were engrafted upon Christianity at Alexandria, and ... which debase the religion until this day" (383). These superstitions persist inter alia in "bibliolatry", church rituals, and a creation narrative that is a mere hang-over from ancient Egypt and that geology has now refuted.

Martineau has been widely understood as saying in Eastern Life that Christianity is merely the last mythology that must now be discarded. That is, her argument is often taken to be that: (1) modern Europeans must leave primitive Egyptian ways behind; (2) Christianity is

\footnotetext{
${ }^{7}$ Indeed, Eastern Life became the best-known Higher-Critical work in English up to that point. See Roberts, Woman and the Hour, 155-56.
} 
a mere Egyptian relic; so (3) modern Europeans must jettison Christianity. Many of her contemporaries took issue with the presumed anti-Christianity (premise 2), while some recent readers object to her pejorative and Eurocentric judgements about Egypt (premise 1) (see David, Intellectual Women, 70-3; Melman, Women's Orients, 237). Both groups of readers are seeing only one side of Martineau's argument. The other side is that Christianity inherits not only the mythical, ritualistic, superstitious aspects of Egypt but also its noble faith in one god and divine moral government (Eastern Life, 383-4, 400). In trying to purify these ideals, Jesus sought to realize the valuable core of Egyptian religion more fully than the Egyptians had done themselves. This respect in which Christianity remains Egyptian does not debase the progeny but ennobles ancestry and progeny alike, for "the great guiding Ideas of mankind are the more ... venerable for having wrought for some thousands of years longer than we had imagined" (208). So, regarding the choice that Martineau effectively puts to Christians, she herself affirms both sides of it: Christianity is debased by the superstitions it inherits from Egypt, but it retains a noble core inherited from Egypt as well.

Martineau's overall conception of historical progression, then, is this. The original Egyptian religion was a hybrid of noble faith and base superstition. Historical progression across the world religions has occurred through their successive attempts to purify the noble from the base components. But the latter components have such tenacious hold that each attempt falls back into superstition - although not before rising higher in the purity scale than the stage preceding it (466; and Autobiography, 2: 287). That is, each time around, the core noble ideas are raised to greater purity - for instance, from Egyptian monotheism-inpolytheism to Judaic monotheism-with-titulary-God to Christian pure monotheism. 
Christianity is thus the highest stage so far. ${ }^{8}$ By implication, the contemporary task is to purify Christianity of its residual superstitions, rituals, and myths, thereby releasing its moral potential. To do this, though, would not be simply to purge Christianity of Egyptian residues; it would also fulfil the potential contained in Egyptian belief.

But here the secularist implication comes in. For Martineau, Christianity as inherited today is thoroughly infused with myths, which pervade such core ideas as those of Jesus' divine origins and resurrection, and of immortal souls. If purified of myth, the Christian religion would not remain as a religion at all. To purify Christianity would be to secularize it. If the noble core of monotheism were extricated from mythic belief in a creator God who is imagined as a person, what would be left? The recognition that the universe is law-governed throughout, its laws forming a unity and holding invariably, but where we cannot possibly know about any creative agency "behind" them (Autobiography, 2: 184, 290). If we likewise demythologized the idea of divine moral government, what would remain is the idea that we must strive for moral perfection and to render society a perfect fraternity (the secular version of Christ's spiritual kingdom).

These twin ideas of "the infinite" - of the universe as an ordered, law-governed whole and of moral perfection - underlie all religion, Martineau says (Society in America, 3: 225). These pure kernels in all faiths, their fundamental great "Ideas", were always secular

\footnotetext{
${ }^{8}$ A significant qualification concerns Islam, the subject of Part 4 of Eastern Life. Like other European progressivists, Martineau wants to avoid what would seem the natural conclusion that Islam makes yet another purifying effort and is the most advanced religion yet. Her solution is to say that Islam reduced the moral law to empirical precepts, in order to adapt it to the passionate "Oriental" character. Hence Islam is supposedly a step backwards compared with Christianity's orientation towards rational principles.
} 
implicitly, but assumed religious form from being indelibly mixed with myth, superstition, and ritual. Through the historical progression, the Ideas have been extricated more and more from their mythic accretions. The next step will be to cease to "personify" the infinite or attribute moral obligations to a divine legislator, thereby extricating the Ideas so fully from myth that they cease to be religious (Autobiography, 2: 280). This will be the innovation of the modern West, which to date has only ever received Ideas from the East - i.e., ultimately, from Egypt. Now it is the West's time to originate, and do so by secularizing (Eastern Life, 488).

In sum, for Martineau, history is a progression with a telos that consists of the noble metaphysical and moral truths of religion-and-philosophy, which have successively realized and unfolded themselves through the sequence of world religions from East to West. This telos was already implicitly present at the start of history, in Egypt, to drive the process. But successive attempts to realize the telos each stagnate and get buried under accretions. Therefore, further advancement always happens through the attempt to return to the sourceideas and extricate them more fully from the base accretions under which they have become submerged.

\section{Cobbe on the Progression of World Religions}

Cobbe was another intellectual powerhouse of the Victorian era. A leading campaigner for women's rights, welfare reform, and against vivisection and cruelty to animals, she was at the heart of British intellectual life in the second half of the nineteenth century, the interlocutor of virtually every influential figure of the time - Darwin, J. S. Mill, Spencer, and Sidgwick among them. A prolific journal contributor, she was "very active in literary labour. Rarely a 
month passes without two or three contributions from her pen in the magazines". 9 These “magazines" were such heavyweight journals as the Contemporary Review, Fraser's Magazine, etc., which were central to Victorian culture. Cobbe approached the topics she campaigned and wrote about philosophically. Her first book was a two-volume treatise on ethical theory, the Essay on Intuitive Morals of 1855 and 1857. She argued that the moral law is divinely legislated, so that morality and religion are indissolubly linked. This provided the starting-point for all her subsequent writings.

Cobbe admired Martineau as a role model of a woman intellectual making a living by writing under her own name. To Cobbe's regret, they never met in person (Life, 2: 203-4). Despite the admiration, Cobbe profoundly disagreed with Martineau's secularism. Cobbe's 1877 essay "Magnanimous Atheism” was directed against Martineau, with Cobbe arguing that morality needs religion and cannot survive without it. Pace Martineau in Eastern Life, it is not that the moral kernel within religion needs extracting from the religious-mythic wrapping; rather, the morality only makes sense along with the religion, and the two must be retained together. Martineau had failed to see that if the religious wrapping was discarded, the moral principles she supported would lose their foundation, and moral life would collapse ("Magnanimous Atheism", 64).

My concern here, though, is with not Cobbe's criticisms of Martineau in “Magnanimous Atheism” but Cobbe's historical account of religion and morality, which she developed in the 1860 s and which informs those later criticisms. This historical account was formulated in contrast with Martineau's picture of the progression through the world-religions to secularism in Eastern Life. Cobbe first read and took notes on Eastern Life while

\footnotetext{
${ }^{9}$ Newspaper clipping about Cobbe, c. 1870, from the Welsh Portrait Collection at the National Library of Wales.
} 
researching religious history in 1851-2 (Mitchell, Cobbe, 76). Eastern Life inspired Cobbe to make her own 11-month tour of Egypt, the Eastern Mediterranean, and Europe in 1857-8. Cobbe refers back again to Eastern Life when leading into her ensuing travel narrative of 1864, Cities of the Past $(2,6)$. Cities of the Past, though, is less philosophical than Eastern Life and more like modern-day travel writing. Cobbe's travels raised fewer philosophical questions for her because they neither convinced her that Egypt was the primal civilization nor decentred her Christian faith. Instead she saw the religions of ancient Egypt and ancient Greece, Judaism, and Islam as approximating to Christianity, containing anticipatory "traces" of it (Cities of the Past, 6-7). Insofar as these other faiths are genuinely religious and moral, they contain the same substance as Christianity - "the simple relation of creature and Creator" - only under different forms (59). All these belief-systems deserve respect and contain some noble truths (61). But it is in Christianity that these noble truths are most fully developed.

Cobbe went on to elaborate and defend this conviction philosophically over the 1860 s, by organizing the world-religions into a progressive sequence culminating in Christianity. She sums up this view in "The Evolution of Morals and Religion" of $1872 .{ }^{10}$

(1) The earliest religious stage is animism, in which natural phenomena are attributed invisible powers. These powers operate capriciously, not morally. "Only through a long

\footnotetext{
${ }^{10}$ Her other relevant essays are "Sacred Books of the Zoroastrians" (1865), "The Brahmo Samaj” (1866), "Max Müller's Chips" (1868), and “Ancient and Medieval India” (1870). Over these essays Cobbe worked out the picture of religious progression summed up in "Evolution of Morals and Religion", subsequently modified to yield her position in "Evolution of the Social Sentiment" of 1874.
} 
upward course ... can the savage be brought to the level whereon he can have any comprehension of goodness" ("Evolution of Morals", 393). ${ }^{11}$

(2) This upward course next yields polytheism, notably that of the ancient Greeks and Romans. Here the gods are seen to administer a system of justice, but morality is still understood merely in terms of positive rules requiring external compliance.

(3) Next, the religions of "partial holiness", above all Judaism and Hinduism, grasp God or the gods as good and, to a degree, loving. Yet this is not fully separated from the requirement to obtain divine love or favour through external compliance with laws or rules and through membership of certain ethnic groups: the Jews or the Brahmins.

(4) Finally, Christianity recognizes one single God who loves everyone alike, and whose love gives us a model of moral action. All are included in the community of subjects loved by God.

Cobbe, then, sees religion and morality having evolved indissolubly together. To that extent, she agrees with Martineau. She also concurs with Martineau in taking an idealist view of history. For Martineau, "the history of Ideas is the only true history" (Eastern Life, 122). Likewise, Cobbe states that the principal vectors of change in human life are ideas and the mind; their history is reflected in the history of religions ("Max Müller's Chips" [1868], 187). However, for Cobbe, religious ideas also spring from and elaborate sentiments, so that systems of ideas and emotions develop in tandem (187-8). Furthermore, Cobbe emphasizes more unequivocally than Martineau that the later stages improve on the earlier ones. For Cobbe, it is only in the retrospective light of the final whole that the earlier stages become intelligible as its incomplete parts. Christianity's "full holiness" extends beyond and includes Judaism's "partial holiness", which extends beyond but includes classical positive rules,

\footnotetext{
${ }^{11}$ Cobbe's concept of animism was informed by Tylor's 1871 work Primitive Culture.
} 
which extend beyond but include animistic negotiation with capricious powers. Thus, unlike Martineau, Cobbe's emphasis is more that the earlier stages embody partial truth than that they embody truth.

Nevertheless, for Cobbe those stages do embody truth, albeit partially - "there are no azoic rocks in the geology of man's religion" (“Sacred Books" [1865], 91). As such, these earlier religious systems deserve respect; after all, the genuine Christian spirit is one of universal community and inclusiveness ("Max Müller's Chips", 189). The germinal truth latent in all religions, their common "substance", is the intuitive sense of dependence on God. At first, within animism, God is merely apprehended as a "dimly discerned Power" (187). Still, however dimly, this idea-cum-feeling of dependence is present from the start, and it eventually becomes completely and explicitly worked out in Christianity.

Cobbe, then, like Martineau, sees the succession of world-religions as progressively realizing a telos that was there at the start. But for Martineau that telos was essentially secular, consisting in ideas of a law-governed universe and moral community. For Cobbe the telos is essentially religious, consisting in the feeling of dependence on the divine. Being essentially religious, this telos finds its fullest development in the Christian idea of a loving God who legislates morality to human agents. And whereas for Martineau successive attempts to purify the "great guiding Ideas" of their religious wrappings have kept falling back into religion, for Cobbe successive religions get better and better at articulating and realizing the original meaning of our dependence on the divine.

Another significant difference between Cobbe and Martineau is that Cobbe includes more world-religions in her progression while jettisoning Egypt. Cobbe classifies the world's major faiths into two triadic groupings ("Sacred Books"). In the East, the primal religion is Hinduism which spawns two breakaways, Buddhism and Zoroastrianism. In the West, the primal religion is Judaism, spawning Islam and Christianity. So whereas most twentieth- 
century accounts of comparative religion include five world religions, Cobbe has six because she includes Zoroastrianism. Treating Zoroastrianism as a sixth major world faith was common in the nineteenth century (see, e.g., Müller, Chips [1867], e.g. xi-xii). For Cobbe, Zoroastrianism is important as the channel by which religious progression moved from East to West, from India to Persia. Also, the Zoroastrians re-focused religion around morality rather than ritual, something that Judaism inherited, so that this moral-and-religious advance thereby reached the West. Unfortunately Judaism then stagnated back into ritual, but Christianity took up the renewal of morality in turn. Thus, within Cobbe's two triads, Zoroastrianism and Christianity are symmetrical counterparts. Zoroastrianism advances over Brahminism in re-emphasizing moral action rather than entrenched ritual, and Christianity advances over Judaism in the same respect (Cities of the Past, 7; "Sacred Books", 91).

Cobbe's progression is not straightforwardly chronological, since she ranks ancient Greek and Roman polytheism below the Eastern religions. This is because Cobbe orders the belief-systems not by time but proximity to Christianity. For her, Christianity's most direct sources lie in the series of world-religions running from Brahminism through Zoroastrianism to Judaism. As this series runs up to Christianity, and anticipates it in "partial holiness", the whole series lies ahead of the classical cultures. This is a different displacement of the classical civilizations from Martineau's, but a displacement nonetheless.

Egypt, though, has dropped out of Cobbe's account. This is emblematic of a broader transition in nineteenth-century European thought in which Egypt lost its status as the originating religious culture to India. Bernal argues that this change had racial motivations, for India was seen as the ancestral site of both the Indo-European language family and the supposed corresponding “Aryan" race (Bernal, Black Athena, 229). Thus the rise of India instead of Egypt was key to the Aryan model. Consistently with that model, Cobbe states that: "By the Aryan and Semitic races has the progress of the world been carried on" ("Max 
Müller's Chips", 195). She notes that Egypt has a doubtful pedigree because its language is related to that of the "Hottentots" (195), who are only at the level of animism in her scheme. Hinduism, she insists, is spiritually much closer to Christianity than the "enigmatical, halfcomprehensible" Egyptian ideas of the Book of the Dead ("Ancient and Medieval India" [1870], 343-4).

A central figure in India's displacement of Egypt was the German-born but Britishbased founder of comparative religion Max Müller, whose 1867 collection Chips from a German Workshop, Vol. 1, Cobbe enthusiastically reviewed, developing her view of the world-religions in dialogue with Müller. In Chips, Müller identifies Christianity as the highest religion, up to which the others lead, although the seeds of true religion - feelings of dependency on the divine, intuitions of moral goodness, and hopes for a better life - pre-exist everywhere. These seeds are only fully realized in Christianity; comparative religion is to show this, proving that Christianity fulfils the aspirations animating all religions. These views influenced Cobbe, as did Müller's demotion of Egypt. For him: "We are by nature Aryan, Indo-European ... : our spiritual kith and kin are to be found in India, Persia, Greece, Italy, Germany; not in Mesopotamia, Egypt, or Palestine" (Chips, 4-5).

Müller elevates the original Vedic faith in stature but sharply distinguishes it from Hinduism's contemporary degenerated reality. Cobbe agrees that the originally pure Vedic faith has long since decayed (Cobbe, "Ancient and Medieval India”, 361). Owing to the supposedly diminished condition of present-day India, Cobbe was comfortable with British rule there. This is in keeping with Orientalist ideology: generally, the more India was deemed noble and pure in the past, the more it was judged stagnant and degraded today, effectively justifying British rule (Said, Orientalism). Still, Cobbe opposed any attempt forcibly to impose Christianity on India. Instead she supported indigenous movements to reform Hinduism and align it with the "moral excellence" of Christ's teachings and the simplicity of 
monotheism ("Brahmo Samaj" [1866], 204-5). Thus, Cobbe gave Hinduism the status of original religion while keeping Christianity at the top of the historical progression. For her, it was in Christianity that the noble kernel of ancient Hinduism was finally realized.

By dropping Egypt from the world-historical progression, Cobbe was working out once more her disagreement with Martineau, especially regarding the telos driving the progression. For Martineau, this telos consisted of core ideas of an ordered universe and a moral community, which are essentially secular and already underlay Egyptian culture. As part of resisting this secularizing account, Cobbe relocates the telos away from Egypt, in ancient India - as the site of a major faith from which she can trace an unbroken religious line up to Christianity.

4. Cobbe on the Progression of Sympathy

Cobbe revised her position in "Sympathy, Heteropathy, Aversion" of 1874, renamed "The Evolution of the Social Sentiment" (hereafter "Social Sentiment") when it was reissued within her 1876 book The Hopes of the Human Race. She now reconceived the moral-religious progression as a world-historical progression in sympathy.

Cobbe defines sympathy as not, properly, an emotion but a source of emotions - and so of actions, for emotions are the "most largely effective springs of human conduct" ("Education of the Emotions" [1888], 223). Roughly, though, 'sympathy' means the feeling of pain at someone else's pain and pleasure at someone else's pleasure ("Social Sentiment", 171). Sympathy realized in action is benevolence, i.e., action to further others' well-being and reduce their suffering. Since benevolence is fundamental to morality, sympathy is a crucial moral emotion. 
To understand Cobbe's concept of sympathy, we can draw on distinctions made by $\mathrm{T}$. H. Irwin apropos of George Eliot's view of sympathy, as embodied in her novels and expressed in her 1856 essay "The Natural History of German Life". ${ }^{12}$ Irwin distinguishes between: (1) cognitive sympathy, the imaginative grasp of what someone else feels in a given situation - i.e., empathy (although the actual word empathy was only coined in the twentieth century); (2) affective sympathy, the tendency to feel what that other person feels; (3) practical sympathy, i.e., treating the other person in a way that considers their interests (Irwin, "Sympathy", 280-1). Given this distinction, we see that Cobbe does not really conceptualize cognitive sympathy at all. ${ }^{13}$ Rather, for her, sympathy means affective sympathy, specifically with respect to the simplifying rubric of pleasures and pains. "Practical sympathy" corresponds to Cobbe's "benevolence", though she understands it as acting to relieve someone's suffering and increase their pleasure.

Cobbe was of her time in foregrounding sympathy, which in "the later decades of the nineteenth century, ... reigned supreme in the Anglo-American intellectual world as a vital social emotion" (Lanzoni, "Sympathy in 'Mind'”, 269, 271). However, Cobbe says that she differs from other moral theorists of sympathy in that they treat sympathy as universal and she does not. Instead, for Cobbe, sympathy has a history - it did not always obtain or prevail. In

\footnotetext{
${ }^{12}$ Cobbe's view of sympathy was not directly influenced by Eliot's; rather, both were operating in an intellectual field where the notion of sympathy figured prominently (see Lanzoni, "Sympathy in 'Mind"').
}

${ }^{13}$ One might wonder whether this was because the word empathy was not yet available. But others such as Eliot had the concept of empathy if not the word; in "Natural History of German Life" Eliot stresses that great literature can bring us to apprehend imaginatively how others feel. 
earlier historical stages, an opposite emotion predominated, heteropathy: pleasure in another's pain and pain at another's pleasure. Thus "the earliest reflected emotion is not sympathetic Pain with Pain, ... but heteropathic Resentment towards Pain, and Displeasure towards Pleasure” (“Social Sentiment”, 176). Heteropathy has only gradually been supplanted, initially by an intermediate emotion, aversion, and afterwards by sympathy - and this through, first, a change in the character of our prevailing emotion from heteropathy to sympathy, and, second, successive extensions of the scope of sympathy.

To show that heteropathy exists, Cobbe appeals to direct observations of children and animals and ethnographic observations of "primitive" tribes (referring to Tylor's 1871 work Primitive Culture). She treats all these observations as being revealing about earlier periods in human history, assuming that individual development (child-to-adult) recapitulates historical development and that the latter involves an ascent from animality to civilization. Animals will often attack and destroy the sick, wounded, aged, or weak: "at the sight of Pain animals generally feel an impulse to Destroy rather than to Help" (“Social Sentiment”, 158). The action is to worsen the other's suffering - i.e., to show cruelty, the opposite of benevolence because the agent takes pleasure in the other's suffering. Institutions like euthanasia and infanticide in "primitive" societies preserve "the evidence of the early sway of the same passion of Heteropathy in the human race in its lowest stage of development" (159). Admittedly, heteropathy is also found at work in modern adults - for example in cruelty to injured animals and helpless children, and domestic violence, as when a husband beating his wife is roused by her injuries and distress to attack her even more furiously. Such behaviours show that heteropathy remains instinctive in us and is only ever overcome through the civilizing process. The same civilizing road that humanity has travelled collectively over the course of history must be travelled afresh by each new generation. Heteropathy is natural and instinctive, sympathy culturally acquired. 
By what stages, then, has sympathy emerged from heteropathy? At first, Cobbe says, the only sympathetic feelings are those of mothers for their children; next, slave-owners or masters come to take selfish pleasure in the pleasures of their slaves or subordinates, seeing that happier subordinates give better service. Once diffused, this attitude weakens heteropathy to a point where aversion becomes prevalent instead, so that instead of piling on to harm the weak, injured, sick, and infirm, people turn away from and avoid them. This is the level the ancient Greeks and Romans had reached: predominant aversion, little sympathy, and still a considerable amount of heteropathy, as in the Roman games. Yet, ironically, these organized displays of cruelty encourage people to take sympathetic pleasure in the pleasures in cruelty that others are taking. By the same mechanism, sympathy grows up within tribes, peoples, and groups that are in conflict, as each group's members sympathize with their fellow-members' pleasures in the sufferings of enemies. Thus heteropathy inexorably undermines itself.

The next step is for people to start to feel pain at others' pain. All the world's "great religions" foster this feeling - most emphatically Christianity, which educates us to feel pain at Christ's sufferings on the cross. However, all these religions have arisen in social contexts where people are used to feeling sympathy only for their own group. These limitations infect the religions, so that they enjoin sympathy only for people of the same nation, race, caste, or creed. "The step over this banner of race ... is an enormous stride", again taken by Christianity, which for the first time extends sympathy to all humanity (191).

Cobbe does not make it explicit, but these stages rework those of "The Evolution of Morals and Religion”. Animism corresponds to heteropathy; aversion to the classical civilizations; sympathy limited by racial and other group divisions (i.e., partial sympathy) to the non-Christian world religions; and complete sympathy to Christianity. In Christian European civilization, group limitations are finally being overcome, so that modern Europeans increasingly regard any "barrier to perfect sympathy" as "a blot on our 
civilization" ("Social Sentiment", 199). Yet various de facto barriers remain - in American slavery; between warring European nations; and between institutional churches and religious denominations. We need to extend our sympathies more consistently, fully, and equally across geographical, racial, and class divisions (Cobbe praises Dickens's novels for encouraging the latter); extend sympathy to non-human animals; and institutionalize sympathy as “organized Charity” (187), for instance with hospitals and social care. She evokes an inexorable movement towards ever-widening circles of sympathy, continuing indefinitely and bringing us ever-closer to God's perfection in love.

Cobbe now sees progress in terms of a universalization of sympathy, overcoming racial and national boundaries. But while sympathy is the telos of historical development history's goal being to realize and extend sympathy ever more widely - she insists that this telos itself emerges historically, that sympathy is historically emergent rather than universal. Yet, despite herself, she is pulled towards seeing at least the seeds of sympathy as having always been at work. Mothers always sympathised with children, and in even the most primitive dominance relationships masters felt some sympathy with their subordinates. And, as Cobbe argues, heteropathy inescapably and immediately produces sympathy: being heteropathic (cruel) themselves, primitive people inevitably sympathize with others who are likewise enjoying heteropathic pleasures. Even from the start, then, sympathy was actively pushing to realize and extend itself.

Although the stages in "Social Sentiment" re-work those in "Evolution of Morals and Religion", Cobbe's two accounts differ as to the telos propelling the historical progression. The seed underpinning all religions is, in her earlier essay, our feeling and idea of dependency on the divine, and in her later essay, the feeling of sympathy with others. Part of the shift in Cobbe's position is to put more weight on the sentiments. She may also seem to have introduced a secular telos that contains no intrinsic religious reference. Not so to her mind. 
The Christian God is the God of love - i.e., of "Supreme Benevolence" (Duties of Women [1881], 32). But "benevolence" is practical sympathy. Thus God is ultimately the God of sympathy, and so it is necessarily in Christianity that the feeling of sympathy is best realized. Cobbe's earlier disagreement with Martineau about religion, then, remains essentially unchanged: for Cobbe the historical progression must culminate in Christianity, not beyond it. There is scope for future historical development, not in intellectual movement past Christianity, but in the ever wider extension of Christian sentiments.

Having said this, by foregrounding sympathy Cobbe has drawn closer to Martineau's earlier position on progress in How to Observe Morals and Manners of 1838 (to which Cobbe never refers; she was presumably unaware of this parallel). There Martineau's general criterion of social progress is that a society is more advanced the more all its members feel part of a whole - a spirit of fraternity that, ideally, should extend to all humanity internationally (How to Observe, 206-7). Martineau then offers four further criteria of progress: (1) how much international intercourse a society has, and how much ethnic and cultural diversity; (2) how far charity is institutionalized; (3) how far the arts and inventions benefit everyone; (4) how widely multiplied people's activities and objects of concern are. The more these conditions are satisfied, the more a society will have a fraternal spirit. Thus, in How to Observe, Martineau measures progress by how widely extended people feel the social whole they are part of to be - that is, how widely people sympathize with others (see, e.g., 211, 219). One's sympathies widen the more activities, people, and groups come into one's interests and concerns: "the more pursuits and aims are multiplied, the more does the appreciation of human happiness expand" (219). Through increased levels of social intercourse, one learns that one can best promote one's own interests by simultaneously furthering the happiness of others; our interests are intertwined. And Martineau sees commerce as one key motor by which such enlarged sympathies can come about (159-60). 
Writing on sympathy in the 1870s, Cobbe was more critical of excessive commercialism, which she feared was undermining moral progress. Accordingly she divides altruism and egoism more sharply than Martineau did in How to Observe. Cobbe holds that my feelings of sympathy with others motivate me to show benevolence to these others for their sake, not mine. My pain at your pain motivates me to reduce your pain, not in order to reduce the pain $I$ feel on your behalf, but because my pain makes me concerned about you . That is, Cobbe looks to sympathy to ground disinterested moral action.

But although Cobbe divides other- from self-regarding action more sharply than Martineau, they agree that progress comes from sympathy becoming extended ever more widely and universally. This universalist stance led them both to be broadly supportive of the British empire on the grounds that it draws nations together and disseminates universal sympathy. I now want to explore this, and consider how their versions of teleological progressivism are linked to Eurocentrism.

\section{Teleological Progressivism and Eurocentrism}

The Victorians generally thought that they stood at the apex of progress to date.

Progressivism thus tended to justify-cum-exculpate the British empire on the grounds that it was spreading a more advanced culture to less advanced ones, pulling them up the civilizational ladder. Martineau and Cobbe were no exception to these tendencies. Cobbe was comfortable with British rule in India; she affirmed Anglo-Saxon superiority and the civilizing power of European culture; and she opposed Irish independence (see Cobbe, "Fenian 'Idea'"). For her part Martineau supported the British empire so long as it either advanced "barbarous" countries or helped formerly great ones to rejuvenate themselves, 
although she thought that once colonies had left "minority" status they should become independent. $^{14}$

Cobbe and Martineau's explicit views on empire are informed by their progressivist theories of history. For Martineau in How to Observe, the British empire has the merit of drawing formerly separated societies and cultures together, encouraging increased social intercourse and diversity and expanding everyone's sympathies. In Eastern Life, as Martineau sketches at the book's end, the world-historical progression has moved from East to West and will advance onwards in the West. Egyptian culture was once vital, but it has long since stagnated, the torch of dynamism passing to modern Europe (Eastern Life, 488; and see Rees, Writings on the Nile, 41-5). By implication, the British empire is justified insofar as it spreads advanced Western thinking to Eastern regions that have become stuck at lower historical levels and cannot pull themselves up by their own momentum.

Cobbe agrees about the stagnancy and "corruption" of the East, although by "the East" she primarily means not Egypt but India (e.g., "Ancient and Medieval India”, 201), reflecting India's displacement of Egypt as the locus of "the East" over the British nineteenth century. For Cobbe, it is India that came first, producing the Vedic culture from which all other worldreligions have grown; but India has long since regressed. Advancement has passed along the line of world-religions, moving from East to West and concluding with Christianity, which is most advanced in virtue of the universality of its moral concern. As such, the British empire is justified inasmuch as it diffuses this Christian spirit.

\footnotetext{
${ }^{14}$ See, on Martineau and empire: Dzelzainis and Caplan, Harriet Martineau, Logan, Harriet Martineau, Victorian Imperialism, esp. 9, 12, and Logan, Harriet Martineau's Writings; on Cobbe and empire: Hamilton, "Making History", Peacock, Theological and Ethical Writings, ch. 3, and Suess, "Colonial Bodies".
} 
Martineau's and Cobbe's theories of progress share an underlying structure. Progressive advancement occurs along a line of world-religions, which realize in successively improving forms a goal that is reaching fruition in the modern West. For both women, then, worldreligions embody different civilizational stages - although for Cobbe the most advanced stage is Christian, whereas for Martineau Christianity is only the penultimate stage and secularization must supersede it. Still, this religious disagreement arises within a shared structure.

One way to understand this structure can be taken from Enrique Dussel's work. Dussel criticizes narratives of modernization and progress which are based solely on intra-European developments: the Reformation, French Revolution, Industrial Revolution, etc. For Dussel, such "internalist" narratives overlook how European ideas of modernity and progress depended on Europe's colonial dominance over the rest of the world. This material system of economic power was the necessary condition of modern Europeans' sense of standing at the summit of progress. Europe's supposedly purely 'internal' developments had a material basis in its 'external' relations with, and dependence on, the regions it had colonized (see Dussel, Invention of the Americas).

Europe's material dependence on its 'other' has an intellectual and theoretical analogue. To articulate how their civilization was most advanced, modern Europeans had to locate it intellectually vis-à-vis other, non-European world civilizations - to spell out "more advanced than all these other cultures, because...". To justify Europe's 'internal' selfconception as the most advanced stage, one had to engage with other, 'external', cultures and so theorize how they were less advanced yet tending in the same direction as modern Europe.

Accordingly, both Martineau and Cobbe informed themselves heavily about nonEuropean civilizations, especially their religious and philosophical belief-systems. Indeed, Martineau and Cobbe knew much more about those belief-systems - e.g., ancient Egyptian 
philosophy in Martineau's case and Eastern religions in Cobbe's case - than most professional Western philosophers of the twentieth century. Cobbe and Martineau did not hesitate to identify these non-European belief-systems as being genuinely both philosophical and religious. Admittedly, they learnt about other cultures in order to arrange them in an ascending series culminating in modern Europe; but, still, they learnt about them.

Moreover, their teleological progressivism contains strands that moderate its overall Eurocentrism. First, Cobbe and Martineau insist that Europeans must approach non-European cultures and belief-systems sympathetically, recognising that every religion contains some noble truths. Otherwise, after all, one will never see how these religions anticipate the outlook of modern Europeans. Given this sympathetic approach, Cobbe praises the moral theory of Zoroastrianism (e.g. Duties of Women, 33-4) and the Buddhist practice of mettā or lovingkindness (e.g. "Social Sentiment", 219), also noting that Islamic and Hindu cultures surpass Christian ones in kindness to animals (213). Martineau found much to commend in ancient Egyptian religious philosophy, and sought to make sense of practices like mummification which her contemporaries found repugnant.

Second, for Cobbe and Martineau, Europe is advanced only in giving the fullest realization so far to ideas, values, and aspirations that have animated all the world's religious cultures. This suggests that the dynamic energy powering historical development is there at the origin - i.e., on this historical scheme, in the East. So Cobbe and Martineau do not view European culture as having its roots in classical Greece where the Greeks were a uniquely innovative people who single-handedly originated Western culture. That idea became entrenched over the nineteenth century, a trend bound up with the drive to diminish Egyptian, and so African, influences on the Greeks, as Bernal shows. Although Cobbe does her bit to minimize Egypt's role, she sees the line of world-religions originating in ancient India as being more directly generative of Christian European culture than classical Greece. Indeed, 
for her, all six world-religions advance beyond than the classical world, which was mired in aversion and cruelty and lacked even the "partial sympathy" of the non-Christian religions. In different ways, then, Martineau and Cobbe both hold that modern Western culture is neither self-contained nor unique but is only the furthest realization of possibilities first envisioned in the East.

So Cobbe's and Martineau's philosophies of history complicate the dominancerelationship of West over East by suggesting that the West depends on the East for its originating ideas, aspirations, and motivations. Reflecting this, neither Cobbe nor Martineau understand progress in simple linear terms. Rather, they subscribe to a spiral view of progress: the "strange law of human progress whereby all human races, and mayhap all human individuals, ascend as it were in spiral lines, coming round again in each revolving period somewhere near, yet above, the past" (Cobbe, "Brahmo Samaj”, 203). For Cobbe, each wave of progress happens through an attempt to return to older source-ideas and values that have stagnated or become degraded. For instance, the Reformation returned to core Christian values (203); before that, Christianity sought to return to and complete the "partial holiness" of preceding religions; those religions in turn only realized and expressed our earlier, more basic feelings of dependency on God. Cobbe's spiral view, then, is that history only ever moves forward by going back deeper into its original motivations and well-springs.

Martineau does not overtly adopt the spiral metaphor but, like Cobbe, she thinks that each wave of religious progression happens through the attempt to purify and extricate earlier ideas from ignoble accretions. Since those ideas were already the purification of yet earlier ideas, progress happens through successive attempts to return to, distil, and reactivate the source. Thus Martineau, too, implicitly supports the spiral view on which we move forward only by going back deeper into the origin. History's end is in its beginning; as such, the West 
never leaves the East behind, but moves forward only by drawing out the well-springs of potential of the East.

\section{Conclusion}

I have reconstructed Martineau's and Cobbe's contributions to the philosophy of history and argued that they developed original versions of teleological progressivism. Both women maintain that a world-historical progression has taken place through a series of religions that are linked to stages in the development of civilization. For Martineau, although Christianity is the most advanced religion in this series, the progression must now move past Christianity and past religion altogether. This is because history's goal or telos is to realize two noble ideas - the ideas of a law-governed universe and a universal moral community - which were the core and kernel of all religions, but must now be extricated from the religious myths by which they have so far been compromised. For Cobbe, contra Martineau, the progression of world-religions culminates in Christianity. Further developments are to come not from secularization, but from the ever more universal extension of Christian ideas and sentiments. The seed of all religion, and the telos driving history, is, in Cobbe's first account, human feelings of dependence on the divine, and, in her second revised account, sentiments of sympathy with others. Under both characterizations the seed is most fully realized in Christianity.

Despite their religious disagreement, Martineau's and Cobbe's accounts of the historical progression share a theoretical structure, in which an original telos becomes realized through successive civilizational stages culminating in modern Europe. These women's accounts of history are thus structurally Eurocentric. However, they also hold the "spiral view" that advancement occurs only through the fuller realization of aspirations and motivations that 
originated outside Europe. Their Eurocentrism is thus more complicated and ambiguous than we might have thought.

\section{BIBLIOGRAPHY}

Barrell, John. "Death on the Nile: Fantasy and the Literature of Tourism 1840-1860", Essays in Criticism, 61, no. 2 (1991): 97-127.

Bernal, Martin. Black Athena: The Afroasiatic Roots of Classical Civilization, vol. 1. New Jersey: Rutgers University Press, 1987.

Boucher-Rivalain, Odile. "Harriet Martineau (1802-1876), from Unitarianism to Agnosticism". Cahiers victoriens et édouardiens 76 (2012): 27-43.

Cobbe, Frances Power. An Essay on Intuitive Morals. Vol. 1. London: Trübner, 1864. Originally published in 1855 .

Cobbe, Frances Power. The Cities of the Past. London: Trübner, 1864.

Cobbe, Frances Power. "The Sacred Books of the Zoroastrians". In Studies New and Old of Ethical and Social Subjects. London: Trübner, 1865.

Cobbe, Frances Power. “The Fenian 'Idea””. Atlantic Monthly 17 (1866): 572-7.

Cobbe, Frances Power. “The Brahmo Samaj”. Fraser’s Magazine 74 (1866): 199-211.

Cobbe, Frances Power. “Max Müller's Chips”. Fraser’s Magazine 77 (1868): 187-204.

Cobbe, Frances Power. “Ancient and Medieval India”. Fraser's Magazine 81 (1870): 343-61.

Cobbe, Frances Power. "Darwinism in Morals". In Darwinism in Morals and Other Essays. London: Williams \& Norgate, 1872. Originally published in 1871.

Cobbe, Frances Power. "The Evolution of Morals and Religion”. In Darwinism in Morals and Other Essays. London: Williams \& Norgate, 1872. 
Cobbe, Frances Power. "The Evolution of the Social Sentiment". In The Hopes of the Human Race. London: Williams \& Norgate, 1876. Originally published in 1874.

Cobbe, Frances Power. The Duties of Women. Boston: Ellis, 1881.

Cobbe, Frances Power. "Magnanimous Atheism”. In The Peak in Darien, with Some Other Inquiries. London: Williams \& Norgate, 1882. Originally published in 1877.

Cobbe, Frances Power. "The Education of the Emotions". Fortnightly Review 43 (1888): 22336.

Cobbe, Frances Power. Life of Frances Power Cobbe, by Herself. 2 vols. London: Bentley, 1894.

David, Deirdre. Intellectual Women and Victorian Patriarchy: Harriet Martineau, Elizabeth Barrett Browning, George Eliot. Basingstoke: Macmillan, 1987.

Dussel, Enrique. The Invention of the Americas, trans. M. D. Barber. New York: Continuum, 1995. Originally published in 1992.

Dzelzainis, Ella and Cora Kaplan, eds. Harriet Martineau: Authorship, Society and Empire. Manchester: Manchester University Press, 2010.

Eliot, George. "Prospectus of the Westminster and Foreign Quarterly Review". In Selected Essays, Poems and Other Writings, edited by A. S. Byatt and Nicholas Warren, 4-8. Harmondsworth: Penguin, 1990. Originally published in 1852.

Eliot, George. "The Natural History of German Life.” In Essays of George Eliot, edited by Thomas Pinney, 266-299. New York: Columbia University Press, 1963. Originally published in 1856.

Gange, David. Dialogues with the Dead: Egyptology in British Culture and Religion, 18221922. Oxford: Oxford University Press, 2013. 
Hamilton, Susan. "Making History with Frances Power Cobbe: Victorian Feminism, Domestic Violence, and The Language of Imperialism". Victorian Studies 43, no. 3 (2001): 437-60.

Hoecker-Drysdale, Susan. Harriet Martineau: First Woman Sociologist. Oxford: Berg, 1991.

Irwin, T. H. "Sympathy and the Basis of Morality". In A Companion to George Eliot, edited by Amanda Anderson and Harry E. Shaw, 279-93. Oxford: Blackwell, 2013.

Lanzoni, Susan. "Sympathy in 'Mind' (1876-1900)". Journal of the History of Ideas 70, no. 2 (2009): 265-87.

Logan, Deborah. Harriet Martineau, Victorian Imperialism, and the Civilizing Mission. Farnham: Ashgate, 2010.

Logan, Deborah, ed. Harriet Martineau's Writings on the British Empire. 5 vols. London: Pickering \& Chatto, 2004.

Martineau, Harriet. How to Observe Morals and Manners. London: Knight, 1838.

Martineau, Harriet. Society in America. 3 vols. London: Saunders \& Otley, 1839.

Martineau, Harriet Eastern Life: Present and Past. New, illustrated 1-volume edn. London: Moxon, 1875. Originally published in 1848.

Martineau, Harriet, ed. and trans. The Positive Philosophy of Auguste Comte. 2 vols. London: Chapman, 1853.

Martineau, Harriet. Autobiography. Reprint edn of the first 2 vols. London: Virago, 1983. Originally published in 1877.

Melman, Billie. Women's Orients: English Women and the Middle East, 1718-1918. Ann Arbor: University of Michigan Press, 1992.

Meyers, Mitzi. "Harriet Martineau's Autobiography: The Making of a Female Philosopher". In Women's Autobiography: Essays in Criticism, edited by Estelle Jelinek, 53-70. Bloomington: Indiana University Press, 1980. 
Mitchell, Sally. Frances Power Cobbe: Victorian Feminist, Journalist, Reformer.

Charlottesville VA: University of Virginia Press, 2004.

Müller, Max. Chips from a German Workshop, vol. 1. London: Longmans, Green \& Co., 1867.

Peacock, Sandra J. The Theological and Ethical Writings of Frances Power Cobbe, 18221904. Lewiston: Edwin Mellen, 2002.

Petersen, Linda H. Victorian Autobiography: The Tradition of Self-Interpretation. New Haven: Yale University Press, 1986.

Rees, Joan. Writings on the Nile: Harriet Martineau, Florence Nightingale, Amelia Edwards. London: Rubicon Press, 1995.

Roberts, Caroline. The Woman and the Hour: Harriet Martineau and Victorian Ideologies. Toronto: University of Toronto Press, 2002.

Said, Edward. Orientalism. Harmondsworth: Penguin, 1991. Originally published in 1978.

Suess, Barbara A. "Colonial Bodies and the Abolition of Slavery: A Tale of Two Cobbes". Slavery \& Abolition 37, no. 3 (2016): 541-60.

Tylor, Edward B. Primitive Culture. 2 vols. London: Murray, 1871.

Weiner, Gaby, and Valerie Sanders, eds. Harriet Martineau and the Birth of Disciplines: Nineteenth-Century Intellectual Powerhouse. London: Routledge, 2017. 